\title{
Cattle Diets on Seeded Clearcut Areas in Central Interior British Columbia
}

\author{
DEE A. QUINTON
}

\begin{abstract}
The bite count technique was used to estimate the botanical composition of cattle diets for deferred rotation and continuous grazing systems on seeded forest range previously clearcut of spruce and pine. There was more variability in diets among grazing periods and years within grazing systems than between grazing systems. Grass, forbs, and shrubs averaged $58.5 \%, 33.5 \%$, and $9 \%$ of the diet, respectively. Orchardgrass, timothy, bromegrass, horsetail, lupine, aster and willow were the major forage species consumed. Diets changed moderately from July through August with a more pronounced change in September. With advanced maturity of grass during dry years, forb usage increased, with some instances of use as high as $54 \%$ of the diet.
\end{abstract}

Much of the central interior of British Columbia above $1,000 \mathrm{~m}$ elevation is characterized by stagnant stands of Engelmann spruce (Picea engelmanii) and lodgepole pine (Pinus contorta var latifolia) with little understory. In recent years many areas that were clearcut or burned by wildfire have been seeded with nonrhizomatous domestic grasses and legumes to provide a summer forage base for cattle grazing.

The same cleared areas are important to foresters for sustained yield of wood. Thus natural regeneration or plantation planting and growth of conifers is of prime importance on the same land that is vital to sustained grazing. These 2 uses are not always compatible so land use becomes an issue.

An initial study to resolve the issue of grass production and grazing on tree production was initiated by Clark and McLean (1978), who reported satisfactory tree survival and growth when proper grazing techniques were followed. In continuing to resolve this issue, this study reports an initial documentation of cattle diets under 2 grazing management practices designed to protect silviculture interests while providing management alternatives to cattle producers. This information is valuable to land managers in prescribing future seedings and to resource managers in prescribing grazing management of cleared areas that are being reforested.

\section{Site and Procedures}

The study area consisted of 2 adjacent sites that were clearcut and slash burned as a post logging treatment. Site 1 consisted of 80 ha at $1,219 \mathrm{~m}$ elevation that had been planted to lodgepole pine and Engelmann spruce in 1971 . The entire site, less a 12 ha control strip, was seeded by air in 1972 with a grass-legume mix consisting of timothy (Phleum pratense), orchardgrass (Dactylis glomerata), bromegrass (Bromus inermis), intermediate wheatgrass (Agropyron intermedium), and alsike clover (Trifolium hybridium).

Site 2 consisted of 40 ha at $1,300 \mathrm{~m}$ clevation that was left for natural tree regeneration following logging operations in 1974. This site was seeded by air with the above grass-legume mix in 1975.

Soils on both sites were classified to be imperfectly drained Brunisolic Gray Luvisols developed on coarse textured, morainal deposits that are hummocky or shallow over bedrock (Canadian system; Young 1980). Imperfectly drained Degraded Eutric Brunisol soils occur on fluvial deposits on old glacial stream channels. Areas of the Luvisol soils are traversed by small streams with

\footnotetext{
Author is range scientist, Agriculture Canada Research Station, 3015 Ord Road, Kamloops, B.C., Canada V2B 8 A9

Manuscript accepted November 9, 1983.
}

continuous flows.

Temperature from May through September ranged from a maximum of $32^{\circ} \mathrm{C}$ to a low of $-6^{\circ} \mathrm{C}$. Mean temperatures were $9.1^{\circ} \mathrm{C}$, $14.5^{\circ} \mathrm{C}, 17.2^{\circ} \mathrm{C}, 16.9^{\circ} \mathrm{C}$ and $11.1^{\circ} \mathrm{C}$ for May, June, July, August and September, respectively. The frost-free period was 112 days. The average May-October precipitation was $170 \mathrm{~mm}$ (Atmospheric Environment Service 1977-79).

Both sites had been previously cross fenced to produce a total of 6 20-ha pastures that were relatively uniform in plant community composition and topography. A careful survey of the area indicated that replicates were not available. Consequently, 3 pastures were randomly selected for rotational grazing with the restriction that 1 must come from site 2. Pastures $B, D$, and F were designated for deferred rotational grazing and pastures A, C, and E for continuous grazing. Initial stocking rates were 1.25 ha per AUM with mature cows with calves. This gave 15 head per grazing treatment with 5 head in each of the 3 continuous grazed pastures. Stocking rates on site 2 subsequently increased by 1 AUM to maintain 50\% utilization of the major grasses.

Diet estimates were taken as if 1 rotation and 1 continuous grazing herd were present on the study area. Trained personnel observed cattle from horseback using a bite count technique, noting plant part and bite size of each species ingested (Reppert 1960, Free et al. 1971). A minimum of 8 cows per grazing treatment were observed for 3 hours in the morning and afternoon of 3 consecutive days per month. Data were collected only from the pasture being rotational grazed and the immediately adjacent continuous grazed pastures. Estimates were not taken for a period of 7 days before or after cattle were introduced to a new pasture.

Each forage species consumed by cattle was hand clipped simulating the noted bite size of each plant part eaten. Diet composition was converted from number of bites to weight, and the relative percentage of each forage species in cattle diets was calculated. Differences in cattle diets between grazing treatments among years and months were determined by analysis of variance. Indices of similarity of diets were calculated using Kulcynzski's formula (Oosting 1956).

One thousand modified loop readings along $3 \quad 335-\mathrm{m}$ permanent transects were used to determine community composition in each pasture. Forage utilization was estimated when cattle were removed from a pasture by clipping all herbaceous vegetation at 13-mm stubble heights from 10 paired $1-\mathrm{m}^{2}$ quadrats. One of each pair of quadrats was protected from grazing. Total production was estimated from 20 protected $1-\mathrm{m}^{2}$ quadrats per pasture clipped to $13 \mathrm{~mm}$ stubble height in October. Shrub utilization was estimated by noting the use of current years growth on each shrub within a 10-m radius circle of each paired plot (Dix 1961).

Differences in community composition were determined by multivariate analysis of variance and the association analysis method of Williams and Lambert $(1959,1960)$.

\section{Results and Discussion}

The community composition among pastures was not significantly different $(P<.05)$ for the major species with the exception of aspen (Populus tremuloides). Aspen was sparse in pastures $\mathrm{E}$ and F. There was more variabilty among transects within pasture than 
Table 1. Cattle diets by weight and forage production and utilization for seeded clearcuts in central Interior British Columbia. (Data pooled over months and years 1977-1979.)

\begin{tabular}{|c|c|c|c|c|c|c|}
\hline \multirow[b]{2}{*}{ Forage } & \multicolumn{2}{|c|}{$\%$ Diet } & \multicolumn{2}{|c|}{ Production $\mathrm{Kg} / \mathrm{ha}$} & \multicolumn{2}{|c|}{ Utilization $\%$} \\
\hline & $\mathrm{C}^{\mathrm{I}}$ & $\mathbf{R}^{1}$ & $\mathrm{C}$ & $\mathbf{R}$ & C & $\mathbf{R}$ \\
\hline $\begin{array}{l}\text { Grass and grass like (total) } \\
\text { Intermediate wheatgrass (Agropyron } \\
\text { intermedium) } \\
\text { Smooth brome (Bromus inermus) } \\
\text { Orchardgrass (Dactylis glomerata) } \\
\text { Timothy (Phleum pratense) } \\
\text { Sedges (Carex spp) }\end{array}$ & $\begin{aligned} 56 & \pm 10 \\
3 & \pm 2^{*} \\
6 & \pm 6 \\
25 & \pm 10 \\
18 & \pm 11 \\
1 & \pm 1\end{aligned}$ & $\begin{array}{l}61 \pm 12^{2} \\
1 \pm 2^{*} \\
3 \pm 5 \\
27 \pm 11 \\
23 \pm 12 \\
5 \pm 12\end{array}$ & $\begin{array}{l}125 \pm 70 \\
140 \pm 8 \\
427 \pm 210 \\
250 \pm 174 \\
18 \pm 10\end{array}$ & $\begin{array}{l}190 \pm 108 \\
101 \pm 5 \\
335 \pm 180 \\
330 \pm 160 \\
16 \pm 10\end{array}$ & $\begin{array}{l}52 \pm 23 \\
59 \pm 13 \\
51 \pm 4 \\
55 \pm 7 \\
72 \pm 7\end{array}$ & $\begin{array}{l}60 \pm 1 \\
78 \pm 0 \\
50 \pm 9 \\
56 \pm 7 \\
61 \pm 8\end{array}$ \\
\hline $\begin{array}{l}\text { Forbs (total) } \\
\text { Aster (Aster spp) } \\
\text { Fireweed (Epilobium angustifolium) } \\
\text { Horsetail (Equisetum pratense) } \\
\text { Lupine (Lupinus arcticus) } \\
\text { Clover (Trifolium spp) }\end{array}$ & $\begin{aligned} 36 & \pm 10 \\
8 & \pm 4 \\
2 & \pm 1 \\
4 & \pm 4 \\
11 & \pm 14 \\
2 & \pm 1\end{aligned}$ & $\begin{aligned} 29 & \pm 12 \\
6 & \pm 6 \\
1 & \pm 2 \\
10 & \pm 13 \\
4 & \pm 6 \\
3 & \pm 3\end{aligned}$ & $\begin{array}{l}82 \pm 3 \\
65 \pm 30 \\
161 \pm 36 \\
401 \pm 35 \\
30 \pm 7\end{array}$ & $\begin{array}{r}168 \pm 30 \\
88 \pm 19 \\
169 \pm 51 \\
382 \pm 12 \\
19 \pm 9\end{array}$ & $\begin{array}{l}74 \pm 3 \\
47 \pm 31 \\
74 \pm 4 \\
58 \pm 32 \\
86 \pm 2\end{array}$ & $\begin{array}{l}75 \pm 9 \\
35 \pm 20 \\
85 \pm 1 \\
30 \pm 14 \\
92 \pm 3\end{array}$ \\
\hline $\begin{array}{l}\text { Shrubs (total) } \\
\text { Meadow sweet (Spirea lucida) } \\
\text { Willow (Salix spp) } \\
\text { Trembling aspen (Populus tremuloides) }\end{array}$ & $\begin{array}{l}8 \pm 3 \\
1 \pm 5^{*} \\
4 \pm 2 \\
1 \pm 1\end{array}$ & $\begin{array}{c}10 \pm 7 \\
T^{*} \\
4 \pm 4 \\
2 \pm 3\end{array}$ & & & $\begin{array}{r}17 \\
5 \\
3\end{array}$ & $\begin{array}{r}9 \\
15 \\
T\end{array}$ \\
\hline
\end{tabular}

C-continuous grazed, R-deferred rotation grazing.

Mean \pm standard deviation

among pastures. Each pasture contained equivalent sub communities of forage although the juxtaposition of these varied from pasture to pasture.

The mean annual forage production during the 3 study years was $1978 \pm 480 \mathrm{~kg} /$ ha consisting of $59.8 \%$ grasses, $38.7 \%$ forbs, and $1.5 \%$ shrubs. Production was significantly different $(P<.05)$ between sites but not among pastures within sites. Production was $1,500 \pm$ $420 \mathrm{~kg} / \mathrm{ha}$ and $2,750 \pm 530 \mathrm{~kg} / \mathrm{ha}$, respectively, for site 1 and site 2 pastures. Despite the differences, the allotment of grazing treatments to pastures and sampling of the diet only in adjacent pastures resulted in forage being equally distributed $(P<.05)$ between grazing treatments.

During the study, cattle ingested 58 of 69 plant species. Of these, 13 species were consistently used and of major importance in the $\operatorname{diet}$ (Table 1). The continuous grazed cattle ingested an average of 30 species monthly compared to an average of 23 species for rotational grazed cattle.
Intermediate wheatgrass and meadow sweet, both of low frequency in the diet, were the only major species showing significant differences in use between grazing treatments (Table 1 ).

Grasses and sedges made up $58.5 \%$ of the overall diets of cattle. Only 5 grasses were eaten extensively although all 11 grasses identified on the study area were eaten. Orchardgrass (26\%) was the most prevalent grass in cattle diets, followed by timothy $(21 \%)$ and bromegrass $(5 \%)$. Sedges were sparse on the study sites but were readily consumed where available.

The usage of intermediate wheatgrass and timothy was variable among months (Table 2). Intermediate wheatgrass was used most by the continuous grazing cattle during September (Tables 1, 2). Timothy was ingested more during August (24\%) than during September (17\%). Timothy was also subject to greater use in 1978 (33\%) when rains were frequent throughout the summer (Table 3). Bromegrass was used most in 1979 (Table 3). Sedges received heavy use (35\%) by the rotation grazed cattle in September of 1979.

Table 2. Mean and standard deviation of monthly diets of cattle grazing seeded clearcuts in central Interior British Columbia pooled over years (1977-1979).

\begin{tabular}{|c|c|c|c|c|c|c|c|}
\hline \multirow[b]{2}{*}{ Forage } & \multirow[b]{2}{*}{ * } & \multicolumn{2}{|c|}{ July } & \multicolumn{2}{|c|}{ August } & \multicolumn{2}{|c|}{ September } \\
\hline & & $\mathrm{C}^{\prime}$ & $\mathbf{R}^{\mathbf{1}}$ & C & $\mathbf{R}$ & $\mathrm{C}$ & $\mathbf{R}$ \\
\hline $\begin{array}{l}\text { Grasses (total) } \\
\text { Intermediate wheatgrass } \\
\text { Smooth brome } \\
\text { Orchardgrass } \\
\text { Timothy } \\
\text { Sedges }\end{array}$ & * & $\begin{aligned} 64 & \pm 9 \\
2 & \pm 2 \\
11 & \pm 8 \\
24 & \pm 16 \\
19 & \pm 17 \\
3 & \pm 2\end{aligned}$ & $\begin{array}{c}62 \pm 2 \\
T \\
1 \pm 1 \\
32 \pm 5 \\
22 \pm 8 \\
3 \pm 3\end{array}$ & $\begin{aligned} 52 & \pm 1 \\
2 & \pm 0 \\
3 & \pm 2 \\
22 & \pm 9 \\
22 & \pm 10 \\
1 & \pm 5\end{aligned}$ & $\begin{array}{c}72 \pm 5 \\
3 \pm 1 \\
7.0 \pm 7 \\
35 \pm 12 \\
25 \pm 16 \\
T\end{array}$ & $\begin{array}{c}51 \pm 11 \\
6 \pm 6 \\
3 \pm 2 \\
28 \pm 7 \\
13 \pm 5 \\
T\end{array}$ & $\begin{array}{c}52 \pm 16 \\
T \\
2 \pm 2 \\
13 \pm 2 \\
20 \pm 15 \\
12 \pm 20\end{array}$ \\
\hline $\begin{array}{l}\text { Forbs (total) } \\
\text { Aster } \\
\text { Fireweed } \\
\text { Horsetail } \\
\text { Lupine } \\
\text { Clover }\end{array}$ & * & $\begin{array}{r}26 \pm 8 \\
5.3 \pm 1 \\
1 \pm 1 \\
7 \pm 7 \\
3 \pm 6\end{array}$ & $\begin{aligned} 32 & \pm 3 \\
9 & \pm 10 \\
2 & \pm 3 \\
13 & \pm 5 \\
3 & \pm 3\end{aligned}$ & $\begin{array}{c}38 \pm 3 \\
14 \pm 2 \\
3 \pm 1 \\
3 \pm 2 \\
8 \pm 13 \\
2 \pm 1\end{array}$ & $\begin{array}{c}23 \pm 4 \\
8 \pm 3 \\
1 \pm 5 \\
1 \pm 0 \\
6 \pm 10 \\
1 \pm 1\end{array}$ & $\begin{array}{c}42 \pm 12 \\
4 \pm 1 \\
1 \pm 1 \\
4 \pm 1 \\
27 \pm 8 \\
1 \pm 1\end{array}$ & $\begin{aligned} 31 & \pm 20 \\
2 & \pm 2 \\
2 & \pm 2 \\
17 & \pm 20 \\
5 & \pm 2 \\
4 & \pm 5\end{aligned}$ \\
\hline $\begin{array}{l}\text { Shrubs (total) } \\
\text { Meadow sweet } \\
\text { Willow } \\
\text { Trembling aspen }\end{array}$ & & $\begin{array}{l}9 \pm 5 \\
1 \pm 5 \\
5 \pm 4 \\
T\end{array}$ & $\begin{array}{l}6 \pm 4 \\
T \pm 4 \\
T\end{array}$ & $\begin{array}{l}9 \pm 2 \\
1 \pm 5 \\
4 \pm 2 \\
1 \pm .5\end{array}$ & $\begin{array}{l}6 \pm 1 \\
T \\
2 \pm 2 \\
T\end{array}$ & $\begin{array}{l}7 \pm 1 \\
1 \pm 5 \\
2 \pm 6 \\
2 \pm 6\end{array}$ & $\begin{array}{c}17 \pm 16 \\
T \\
11 \pm 13 \\
5 \pm 3\end{array}$ \\
\hline
\end{tabular}

${ }^{1}$ C-continuous grazing, R-deferred rotation grazing.

*Significant difference between months at .05 level. 
Table 3. Mean and standard deviation of yearly dits of cattle grazing seeded clearcuts in central Interior British Columbia pooled over grazing periods.

\begin{tabular}{|c|c|c|c|c|c|c|c|}
\hline \multirow[b]{2}{*}{ Forage } & \multirow[b]{2}{*}{$*$} & \multicolumn{2}{|c|}{ July } & \multicolumn{2}{|c|}{ August } & \multicolumn{2}{|c|}{ September } \\
\hline & & $\mathrm{Cl}$ & $\mathbf{R}^{\prime}$ & $\mathrm{C}$ & $\mathbf{R}$ & C & $\mathbf{R}$ \\
\hline $\begin{array}{l}\text { Grasses (total) } \\
\text { Intermediate wheatgrass } \\
\text { Smooth brome } \\
\text { Orchardgrass } \\
\text { Timothy } \\
\text { Sedges }\end{array}$ & $*$ & $\begin{aligned} 54 & \pm 10 \\
3 & \pm 3 \\
2 & \pm 1 \\
29 & \pm 10 \\
15 & \pm 5 \\
2 & \pm 2\end{aligned}$ & $\begin{array}{l}56 \pm 18 \\
1 \pm 2 \\
3 \pm 1 \\
28 \pm 14 \\
19 \pm 6 \\
2 \pm 4\end{array}$ & $\begin{array}{c}63 \pm 11 \\
3 \pm 2 \\
7 \pm 7 \\
21 \pm 13 \\
30 \pm 10 \\
1 \pm 1\end{array}$ & $\begin{array}{c}61 \pm 7 \\
T \\
1 \pm 1 \\
22 \pm 9 \\
36 \pm 4 \\
T\end{array}$ & $\begin{aligned} & 50 \pm 6 \\
& 4 \pm 2 \\
& 9 \pm 7 \\
& 24 \pm 8 \\
& 8 \pm 3 \\
& T\end{aligned}$ & $\begin{aligned} 69 & \pm 8 \\
1 & \pm 2 \\
7 & \pm 7 \\
30 & \pm 15 \\
13 & \pm 9 \\
12 & \pm 20\end{aligned}$ \\
\hline $\begin{array}{l}\text { Forbs (total) } \\
\text { Aster } \\
\text { Fireweed } \\
\text { Horsetail } \\
\text { Lupine } \\
\text { Clover }\end{array}$ & * & $\begin{aligned} 39 & \pm 8 \\
7 & \pm 6 \\
2 & \pm 1 \\
8 & \pm 6 \\
12 & \pm 20 \\
2 & \pm 1\end{aligned}$ & $\begin{array}{c}37 \pm 15 \\
3 \pm 4 \\
2 \pm 2 \\
20 \pm 20 \\
3 \pm 5 \\
3.0 \pm 3\end{array}$ & $\begin{array}{l}29 \pm 12 \\
9 \pm 5 \\
T \\
2 \pm 1 \\
14 \pm 12 \\
1.0 \pm 1\end{array}$ & $\begin{array}{c}24 \pm 12 \\
9 \pm 11 \\
T \\
4 \pm 3 \\
7 \pm 9 \\
T\end{array}$ & $\begin{array}{l}39 \pm 10 \\
8 \pm 4 \\
2 \pm 1 \\
4 \pm 1 \\
8 \pm 14 \\
2 \pm 1\end{array}$ & $\begin{array}{c}24 \pm 5.5 \\
7 \pm 4 \\
1 \pm 5 \\
6 \pm 6 \\
2 \pm 3 \\
4 \pm 5\end{array}$ \\
\hline $\begin{array}{l}\text { Shrubs (total) } \\
\text { Meadow sweet } \\
\text { Willow } \\
\text { Trembling aspen }\end{array}$ & & $\begin{array}{l}6 \pm 3 \\
1 \pm 5 \\
2 \pm 1 \\
1 \pm .5\end{array}$ & $\begin{array}{l}7 \pm 2 \\
T \\
1 \pm .5 \\
2 \pm 2\end{array}$ & $\begin{array}{l}8 \pm 2 \\
1 \pm .5 \\
4 \pm 3 \\
T\end{array}$ & $\begin{aligned} 15 & \pm 16 \\
1 & \pm 1 \\
10 & \pm 14 \\
3 & \pm 4\end{aligned}$ & $\begin{array}{l}11 \pm 4 \\
1 \pm .5 \\
5 \pm 3 \\
1 \pm 1\end{array}$ & $\begin{array}{l}7 \pm 3 \\
T \\
2 \pm 4 \\
1 \pm 1\end{array}$ \\
\hline
\end{tabular}

'C-continuous grazing, R-deferred rotation grazing.

-Difference between years is significant at .05 level.

Other patterns of use or avoidance of important grasses in cattle diets were not evident. This was due to the continuous availability of palatable forage species at all times during the summer and to constant summer regrowth following grazing.

Several researchers have shown that grasses were the main component of cattle diets (Cook et al. 1963, Van Dyne and Heady 1965, Cook et al. 1967, Mackie 1970, Skovlin et al. 1976, McLean and Willms 1977, Willms et al. 1980, Holechek et al. 1982a). My pooled data support this (Tables $1,2,3$ ). However, unpublished data show grasses and sedges varied from a low of $33 \%$ of the diet for continuous grazed cattle during September of 1977 to a high of $77 \%$ of the diet for rotation grazed cattle during July of 1979. Holechek et al. (1982b) reported grass consumption on mountain range in Oregon as low as $36 \%$ of the diet in spring to as high as $83 \%$ of the diet during summer. My unpublished data show that grass was not the major constituent of cattle diets during September 1977 and 1979, when forb usage as high as $54 \%$ occurred. Both years were characterized by cool, wet springs followed by drier than normal periods from mid July to late August. This resulted in partial curing and drying of grasses before September rains and subsequent regrowth.

Forbs constituted $33 \%$ of the overall diet of cattle (Table 1). Twenty-eight of 30 forb species present on the area were ingested by cattle. Five of these were consistently used and of major importance in the diet (Tables 1, 2, 3).

Arctic lupine, horsetail, and aster were the most prevalent forbs in cattle diets accounting for $66 \%$ of the pooled forb usage (Table 1). Forb usage (37\%) was greatest during the driest year (1977) and was lowest (27\%) during 1978, the wettest year (Table 3). Arctic lupine was used seasonally, appearing in diets only after it had matured or had been touched by late summer frosts (Table 2). Arctic lupine was more prevalent in diets of continuous grazed cattle (Table 2). Although arctic lupine was heavily ingested, it did not negatively affect cattle in this area. Other lupines are known to be teratogenic.

Horsetail was most prevalent in the diet during July and September. The highest incidence of use $(42 \%)$ was in the September diet of the rotational grazed cattle. Horsetail has been associated with a serious loss of condition in cattle and a related rapid milk loss (Clarke and Clarke 1975). Since cattle on these sites use considerable amounts of horsetail this needs to be investigated.

Aster was grazed throughout the season with most use occurring during July and August (Table 2).

Shrubs made up about $9 \%$ of the overall pooled diet of cattle
(Table 1). Of 28 woody species identified on the study area, 19 were used as food items. Shrub usage was relatively constant in cattle diets (Table 1, 2, 3). The only high instance of use was by rotation grazed cattle during September of 1978 when $26 \%$ of the diet was willow.

Similarity indices comparing grazing periods over years and grazing periods (Table 4) show that cattle diets were most similar

Table 4. Percent similarity of diets of cattle grazing seeded clearcuts in central Interior British Columbir.

\begin{tabular}{lcccc}
\hline \hline Comparison & $\begin{array}{c}\text { Continuous } \\
\text { grazed }\end{array}$ & $\begin{array}{c}\text { Rotation } \\
\text { grazed }\end{array}$ & Cont./ Rot.' & Rot./Cont. \\
\hline July/Aug & 68 & 57 & 72 & 69 \\
July/Sept. & 58 & 60 & 55 & 56 \\
Aug/Sept & 74 & 49 & 52 & 63 \\
$1977 / 1978$ & 66 & 50 & 52 & 60 \\
$1977 / 1979$ & 64 & 62 & 72 & 50 \\
$1978 / 1979$ & 66 & 52 & 59 & 56 \\
\hline
\end{tabular}

Continuous grazed first date vs. deferred rotation grazed second date.

through the grazing season when grazing a pasture continuously. The higher values for the transition from July/August and August/September and the lower values for the July/September comparisons indicate that the diet changed gradually over the summer. The higher values for the continuous grazed cattle diet are also indicative of grazing patterns where the same plants may be subjected to repeated grazing. The low value for the August/September diet of the rotation grazed cattle reflects less usage of mature and cured orchardgrass and timothy and more use of sedges, forbs, and browse by this group in September.

Comparing years within grazing treatments (Table 4) shows that continuous grazed cattle diets were more repetitive over time and varying conditions. Field notes and weather records show that 1977 was a year with a normal wet spring (110 mm rain) followed by an extended dry period from early July to September with only a light rain ( $5 \mathrm{~mm}$ ) in early August. In contrast, 1978 was a wet year with frequent rains all summer. Nineteen seventy-nine was a dry spring ( $55 \mathrm{~mm}$ rain) with frequent light summer rains and dry periods from July 13 to August 2 and from August 4 to August 13. The rotation grazed cattle diet similarity indices appear to reflect these seasonal climatic patterns with the greater similarity between diets for years with drier summers $(1977 / 79)$. 
Comparisons of continuous and rotation grazed cattle diets among years and months indicate that similarities between continuous and rotation groups were as comparable as comparisons for either continuous or rotation grazed diets for the same time frame (Table 4).

Comparisons of continuous and rotation grazed cattle diets within years and grazing periods indicate that September diets were least similar between groups (Table 5). This was due to

Table 5. Percent similarity of cattle diets trazing seeded clearcuts in central Interior British Columbia, comparing continuous versus deferred rotation graxing treatments within years and grazing periods.

\begin{tabular}{lcccc}
\hline \hline Grazing periods & 1977 & 1978 & 1979 & Overall diet \\
\hline July & 79 & 67 & 65 & 73 \\
August & 67 & 75 & 62 & 70 \\
September & 38 & 45 & 42 & 45 \\
Overall diet & 61 & 73 & 66 & 73 \\
\hline
\end{tabular}

rotation grazed cattle grazing a deferred pasture where most forage had matured compared with the continuous grazed cattle grazing regrowth. The continuous grazed cattle also had greater variety in their September diets, using forbs to a greater degree and utilizing 9 species not consumed by the rotation group during this period.

\section{Conclusions}

Diets of cattle grazing clearcut sites at elevations above $1,000 \mathrm{~m}$ that were seeded to timothy, orchardgrass, intermediate wheatgrass, bromegrass, and alsike clover in central interior British Columbia consist of about $59 \%$ grass, $33 \%$ forbs, and $9 \%$ browse. Overall mean diets of cattle grazing an area continuously over the summer are about $73 \%$ similar to diets of cattle grazing the same area on a deferred rotation basis. Orchardgrass and timothy are the most important grasses consumed by cattle. Lupine, horsetail, and aster are the most important forbs, and willow is the most important browse. Management of clearcuts at this altitude should be based on these species. Season of use and productivity of these plant species should be accounted for when forage allocations are being made for cattle, deer, and moose on these sites.

Cattle diets from these areas change gradually from July through September and from site to site. The most pronounced change is in September diets when cattle are introduced onto a previously ungrazed site. Cattle grazing clearcuts are somewhat selective, seeking the more palatable forage and may depart from a predominantly grass diet. A knowledge of conditions that produce an abundance of forbs and the time of the curing of grasses would help managers optimize use of these ranges.

\section{Literature Cited}

Atmospheric Environment Service. 1977-79. Monthly record meteorological observations in Western Canada. Environment Canada. Downsview, Ontario.

Clark, M.B., and A. McLean. 1978. Compatibility of grass seeding and coniferous regeneration of clearcuts in the south central Interior of British Columbia. British Columbia Min. Forests, Res. Note 83.

Clarke, E.C.C., and M.L. Clarke. 1975. Veterinary Toxicology. Bailliere Tindall, London.

Cook, C.W., J.T. Blake, and J.W. Call. 1963. Use of esophageal fistula cannulae for collecting forage samples from both sheep and cattle grazing in common. J. Anim. Sci. 22:579-581.

Cook, C.W., L.E. Harris, and C.M. Young. 1967. Botanical and nutritive contents of cattle and sheep under single and common use on mountain range. J. Anim. Sci. 26:1169-1174.

Dix, R.L. 1961. An application of the point-centered quarter method to the sampling of grassland vegetation. J. Range Manage. 14:63-69.

Free, J.C., P.L. Sims, and R.M. Hansen. 1971. Methods of estimating dry-weight composition in diets of steers. J. Anim. Sci. 32:1003-1007.

Holechek, J.E., M. Vavra, J. Skovlin, and W.C. Krueger. 1982a. Cattle diets in the Blue Mountains of Oregon, I. Grasslands. J. Range Manage. 239-242.

Mackie, R.J. 1970. Range ecology and relations of mule deer, elk and cattle in the Missouri River Breaks, Montana. Wildl. Monogr. 20.

McLean, A., and W. Willms. 1977. Cattle diets and distribution on springfall and summer ranges near Kamloops, British Columbia. Can. J. Anim. Sci. 57:81-92.

Dosting, H.J. 1958. The study of plant communities. W.H. Freeman and Company, San Francisco.

Reppert, J.N. 1960. Forage preference and grazing habits of cattle at the Eastern Colorado Range Station. J. Range Manage. 13:58-65.

Skovlin, J.K., R.W. Herris, G.S. Strickler, and G.A. Garrison. 1976. Effects of cattle grazing methods of ponderosa pine-bunchgrass range in the Pacific Northwest. USDA Tech. Bull. 1531.

Van Dyne, G.M., and H.F. Heady. 1965. Botanical composition of sheep and cattle diets on a mature annual range. Hilgardia 36:465-492.

Williams, W.T., and J.M. Lambert. 1959. Multivariate methods in plant ecology. I. Association analysis in plant communities. Ecology 47:85-101.

Williams, W.T., and J.M. Lambert. 1960. Multivariate methods in plant ecology. II. The use of an electronic digital computer for association analysis. Ecology 48:689-710.

Willms, W., A. McLean, R. Tucker, and R. Ritcey. 1980. Deer and cattle diets on summer range in British Columbia. J. Range Manage. 33:55-59.

Young, G.K. 1980. Soils Report of the Ashcroft area (921). Soils and landform map 9I/16. British Columbia, Resource Analysis Branch, Ministry of the Environment. 